Marquette University

e-Publications@Marquette

Social and Cultural Sciences Faculty Research and

Publications

Social and Cultural Sciences, Department of

$11-1-2002$

\title{
War and the Contest Over National Identity
}

Roberta Coles

Marquette University, roberta.coles@marquette.edu

Accepted version. The Sociological Review, Vol. 50, No. 4 (November 2002): 587-609. DOI. (C) 2002 Blackwell. Used with permission.

The definitive version is available at www.blackwell-synergy.com. 


\title{
War and the Contest Over National Identity
}

\author{
Roberta L. Coles \\ Sociology Department, Marquette University \\ Milwaukee, WI
}

This paper looks at a recent historical moment in which the American national identity was defined and contested in the public arena. The Persian Gulf crisis of 1990-91 presents a case in point in which official actors attempted to define the American character and in doing so prescribed particular actions necessary to fulfill what it means to be an American. President George Bush's discourse used the crisis to rejuvenate US prestige and American confidence. He described Americans as unique in esteemed values and America as the only country capable of leading the world. In so doing, he invited American participation in support for US military intervention. On the other side, the peace movement chose to emphasize American weaknesses, domestic problems, and the gullible nature of the American people. In so doing, it attempted to shame Americans into supporting the anti-war movement.

Definitions of national identity run parallel to the criteria privileged in definitions of nations. Territory and ethnicity have often been viewed as integral to, if not identical with, nation, although rarely are national boundaries coterminous with ethnic enclaves. The use of a single currency, the patriotism embodied in national anthems, flags and national heroes, a set of common institutions, and a single code of rights and duties for all members are also considered essential to the existence of a national identity (Smith, 1991; Triandafyllidou, 1999).

The Sociological Review, Vol 50, No. 4 (November 2002): pg. 587-609. DOI. This article is @ Blackwell Publishing and permission has been granted for this version to appear in e-Publications@Marquette. Blackwell Publishing does not grant permission for this article to be further copied/distributed or hosted elsewhere without the express permission from Blackwell Publishing. 
In some contexts, the question of national identity is often simply 'In which country do you live?'

However, a nation is more than the land it encompasses, the number or kind of people residing in it, or the political economy it generates. Rather it is, in the words of Benedict Anderson (1991), an 'imagined community' invented through selectively remembered and embellished events, myths, and other imaginings that conceive comradeship and communion regardless of objective realities of inequality and division. Hence, a national identity is more than just which nationality box one checks on a form; it is more than just the recognition, or even delight, that one is a member of a particular national grouping. The reality is that an individual's national identity depends on a multitude of factors: ancestry, citizenry, language, religion, and ideology. But it also depends on the immediate situation in which one is pressed to claim an identity and the qualities and richness of the collective identities offered.

According to Philip Schlesinger (1978), national identity is best understood as a form of collective identity, which, as conceived by Michel Foucault, is a discursive formation, a way of speaking that shapes consciousness. At the same time, it serves as a terrain upon which the content of that consciousness is contested. Like all collective identities, a national identity is a dynamic system of social relations and representations that is continually constituted and reconstructuerd (Schlesinger, 1987). Little of the research that addresses national identity as a collective identity addresses what characteristics constitute any specific national identity and how communicative practices and societal actors contribute to the construction of an anthropomorphic nation (Schlesinger, 1987; Thompson, 2001).

This paper looks at a recent historical moment in which the American national identity was being defined and contested in the public arena. The Persian Gulf crisis of 1990-91 presents a case in point in which official actors attempted to define the American character and in so doing prescribed particular actions necessary to fulfill what it means to be an American. In reaction, the peace movement that coalesced during the crisis offered a collective identity for its potential members and, perhaps unwittingly, challenged the 
official definition of what America is and what it means to be an American. The repercussions of this contestation and the forms of identity offered are discussed.

\section{Collective identity, national identity and war}

New social movement scholars have defined collective identity as a set of attitudes, commitments, and rules of behavior to which collective members are expected to subscribe (Friedman and McAdam, 1992). Such an identity is interactionally constructed (Hunt et al., 1994) and constructed continually, changing over time (Stoecker, 1995). The realization of a common identity motivates participation and enables the formation of a common will and a capacity for collective action (Friedman and Adam, 1992; Norton 1988). Specifically, Taylor and Whittier (1992) identified there components essential to a collective identity: 1) a heightened saliency of common characteristics (a sense of 'we-ness'), 2) consciousness, the interpretative frameworks that emerge from a group's struggle to define and realize its interests, and 3) a set of beliefs critical of, or in opposition to, the dominant order. This latter criterion unnecessarily restricts the concept of collective identity to social movements, when clearly other collectivities, such as nations, also have identities.

While a national identity may not be adversarially juxtaposed to a dominant order, it is imagined in a context of other nations. As Edward Shils (1995) suggests, a national collective self-consciousness entails at least an awareness of other collectivities and an evaluation of self and others. Even when a nation has lost its territoriality, a national identity, nevertheless, locates a particular nation relative to others in the world community. That location may not necessarily be in opposition to the world order or to other nations in the world order, but the process of situating one nation among many frequently results in stereotypical 'us' and 'them' conceptions, which, as Michael Billig (1995), notes, are spoken of as if they result from genetic inheritance.

National identity is daily defined and passed on through a process of political socialization through the arts, media, education, and family. In fact, the process of imagining the national identity is so commonplace that a number of scholars have pointed out that national 
identity is often imperceptibly present, having a taken-for-granted or banal quality (Billig, 1995; Thompson, 2001). However, there are times when national identity becomes more salient. Nothing calls forth more compelling national discourse and an intense need to define or defend national identity than international conflict or war (Bloom, 1990; Calhoun, 1997; McCrone et al., 1998). Indeed, under such a therat, assert Andersen (1991) and Hedetoft (1993), a strong national identity eventually moves its members to self-sacrifice, to a willingness to die for it.

War itself is often analyzed in terms of its geopolitical functions, and the rhetoric that usually attends armed conflict is frequently analyzed in terms of its ability to legitimate war (Dionisopoulos and Goldzwig, 1992; Holsti, 1962; and Ivie, 1974). Occasionally, war is viewed as an individual leader's means to self-legitimation. For example, Richard Barnet's 1990 book on presidents and war posits as truism that presidents build their reputations on foreign policy. He cites Ronald Reagan's assault on Gernada just two days after 241 marines had been killed in Lebanon as one instance of warring to make a president look strong (through rhetorically Reagan himself claimed that the success of the Grenada attack proved America was strong again).

A few anthropologists and psychologists have recognized that war or other forms of violence performs intrinsic functions for the individual participant. For instance, war can fulfill the warrior's riskseeking or play needs (Clarke, 1986). According to Georges Sorel (1941), forms of violence can enhance the individual's selfdevelopment through the alleviation of boredom or piqued creativity and confidence. Franz Fanon (1968) believed violence could lead to personal responsibility and freedom. (See Grundy and Weinstein (1974) for a nice summary of intrinsic justifications of violence.)

But war and its words can be a means by which a society, including those who don't do the actual fighting, defines its national character and legitimates its existence, thereby creating or rekindling a collective identity. At minimum, according to anthropologist Carol Greenhouse (1986), the ability of a society to mobilize for war may be perceived by the members as a sign that their social order is viable. 
However, one might infer then that the nation's sense of viability is greatly dependent on the effectiveness or outcome of the mobilization. Without minimizing the role that a war's outcome can play. 1 I would posit that regardless of outcome war mobilization offers a 'teachable moment' for presidents, an opportunity to spell out specific national qualities that supposedly make a particular nation distinct. In so doing, presidents socialize the nation's members about their collective identity, defining who they are as a sum of individuals, and what their collective role is in the community of nations.

As stated earlier, most identity theories hold that identities of any variety (individual or collective) are formed in a context of juxtaposed categories: that is, one identity can not be defined except in comparison to another, just as some would say that love can't be fully understood without hate, nor joy without pain. Alexander Wendt (1992) postulates that the emergence of a common 'other' is a factor that facilitates collective state identity. Similarly, Ivar Neumann (1999) posits that international relations in general are essentially self/other relations. In his book, Uses of the Other: 'The East' in European Identity Formation. Neumann argues that the European creation of a "Turkish Other" and a "Russian Other" have played important roles in defining what Europeans are or at least what they are not. As an instance of conflictual international relations, war readily creates an 'other,' usually an adversarial other in the form of a country, an ethnic, religious, or ideological group, or a leader. By defining these others as 'uncivilized,' 'barbarian,' 'backward,' 'evil,' etc., a nation begins to define its own identity boundaries.

The deployment of such oppositional identity categories was prevalent in Bush's discourse during the Gulf crisis. Bush's categories tended to be broad and dualistic. For instance, Bush distinguished between force and aggression. According to Bush, aggression, which is what Hussein committed, was evil and force, which was Bush was about do, was good. Force is not aggression: it is punishment of aggression.3 Bush also pointed out that Hussein's war methods, such as the SCUDS, were inferior and weapons of terror, while US 'smart' weapons were superior. Another distinction Bush used was that between the civilized world and the uncivilized, atavistic Hussein. Finally, Hussein aws associated with Hitler.4 According to Philip 
Wander's (1984) and Mary Stuckey's (1992 and 1995) work on 'prophetic dualism,' the effects of this rhetorical strategy are to essentially divide the world into two camps, stifle debate, discourage consideration of alternatives, and demand total victory of good over evil. However, much has been written about the demonization of Saddam Hussein (Rojo, 1995 and Spellman and Holyoak, 1992), so that aspect will not be addressed further here.

Moreover, military battles are frequently accompanied by discursive battles at home between pro-war administration and antiwar social movements. While the direct intent of the discourses of these two adversaries may be to recruit supporters and articulate pragmatic and ideological justification for and against war, in this case they simultaneously painted a landscape of America as a nation among nations and a portrait of the character of the American people, which was then offered to the public for adoption.

This case study looks at that discursive battle over what is America and what it means to be American. The data analyzed are the seven months of press conferences, exchanges with reporters, speeches given by President George Bush made to various audiences. These 285 documents were all recorded in the Weekly Compilation of Presidential Documents (WCPD) from August 2, 1990, the day Saddam Hussein invaded Kuwait, through the six-week war, which began January 16, 1991, and ended February 27, 1991. In addition, printed data, such as press releases, memos, letters to the editors, mailing to memberships, rally flyers, educational material, were obtained from two national peace groups - the National Campaign for Peace in the Middle East (NCPME) and the Military Families Support Network (MFSN).

The MFSN and the NCPME were both formed in reaction to the Gulf crisis. In this sense, they were both new organizations. Both had prevention of the Persian Gulf War as their primary short-term goal. They were both national organizations in that they each drew their supporters from across the United States. The MFSN was headquartered in America's heartland in Milwaukee, Wisconsin, and the majority of people associated with the MFSN were relatives of US military personnel serving in the Gulf. The NCPME, headquartered in 
New York, was a coalition of more than 200 'peace and justice groups,' including SANE/Freeze, Fellowship of Reconciliation, Society of Friends, National Council of Churches, and others. While the two peace organizations had any significant differences in their structure and collective self-identities (see Coles, 1999), their discourse about American national identity will be treated as a whole, with significant differences noted.

Unlike Bush's documentation, little of the peace movement, discourse was systematically gathered and held for public use, so only 73 pieces of data were analyzed for the peace movement. All of the data was repeatedly analyzed and categorized in terms of the qualities, values, and actions Bush or the peace movement attributed to the nation of its members.

\section{Political context of the gulf crisis}

In 1990, as the Cold War was coming to an end and the United States' major enemy, the Soviet Union, was losing control of numerous East European countries and suffering its own demise, it might have been thought that American national identity would have been secure. But, as Lance Bennett (1980: 166) has said, 'new political situation seem to fall quickly into old symbolic molds.' While the disintegration of the 'evil empire,' on one hand, appeared as a victory for western capitalism and its leader, the United States, it also entailed a decline in the need for a military giant. The US Pentagon reluctantly embarked on the downsizing of its armed forces and bases. At the same time, the United States' status as an economic leader was precarious, stemming from strong competition from Japan and Germany.

Prior to this process, a crisis in US public mythology had developed over the past several decades as well (Slotkin, 1992). The United States had suffered its first major military loss in Vietnam, which gave rise to the supposed psychological paralysis that came to be called the 'Vietnam Syndrome.' The 1973 Arab oil boycott and the 1979-80 Iran hostage crisis seemed to prove that America no longer had a freehand in the world. The 1983 US intervention in Lebanon 
resulted in an embarrassing military debacle in which nearly 250 US soldiers were killed in a suicide bomb attack on their compound.

Although the Reagan and Bush administration successfully pulled off several foreign interventions, such as in Panama and Grenada, these paled in size to the Gulf crisis, which over a sevenmonth period entailed the deployment of 250,000 US military personnel, the largest development since the Vietnam War. The former military escapades had been quick strategic interventions: this was war.

Meanwhile, political pundits said the American public was experiencing a 'malaise.' The 1987 publication of Yale historian Paul Kennedy's book The Rise and Fall of the Great Powers contributed to this malaise by concluding that America was experiencing grave and irreversible economic and military decline.5 Time magazine noted that Americans had been haunted by the ghosts of the Vietnam era: selfdoubt, fear of power, divisiveness, and a fundamental uncertainty about America's purpose in the world (Cloud, 1991). Moreover, according to Bruce Miroff's (1998) study of the presidential image during the latter half of the Twentieth Century, President Bush took office during an era when Americans was less deferential and more cynical, and the presidential image had deteriorated in the eyes of most Americans. Even Bush himself was seen as a postmodern president with little ability to shape global affairs, or more colloquially known as the 'wimp factor' (Rose, 1991).

The objective validity of this assessment of America's well being is not the subject here: the perception of reality matters here. In August 1990, apparently heeding the above assessment of a debilitated US mood and capabilities, President Saddam Hussein of Iraq invaded its southerly neighbor Kuwait, a small but wealthy oil kingdom, and claimed ownership of disputed oil fields lying beneath the two countries' borders. During the next seven months President George Bush orchestrated the first large-scale war since Vietnam. To accomplish this, he needed more than guns and ammunition: he needed a motivating vocabulary to accomplish two rhetorical goals. 
First, in the short-run, Bush had to do what, according to John Murphy (1992) and Ernest Bormann (1985), any war requires - create a united rhetorical community, rendering it willing to use all available resources to repulse a threat. Because of the high stakes involved in war, pragmatic justifications (such as oil, jobs, or a way of life) alone cannot muster the public support essential to an elected commanderin-chief. Cecil Crabb, Jr. once wrote that American foreign policy is pragmatic consideration, but leaders still must utilize ideals to legitimize their policy. Without at least the appearance of a worthwhile human purpose, such policy would be unlikely to succeed. ${ }^{6}$

The goal was more difficult in the Persian gulf than it had been in the previous Central American interventions because the Gulf was farther from the United States, little knowledge or sympathy for Arab oil kingdoms existed previously among the American public, and the United States had few military bases in the region. Bush needed time to establish those bases and deploy the personnel and equipment to meet the military challenge. This lengthy military buildup, hefty deployment, and costly intervention created more potential for public awareness and debate of US policy in the Gulf, so Bush's discursive strategy required transcendent emotional appeals that addressed the nation en toto, whether or not all its members were directly affected by the war.

A second goal was to seize the opportunity to dispel self-doubt and restore American virtue, credibility, and leadership, at home as well as abroad. This became especially clear during the war, when Bush spoke directly about what the struggle was achieving for America in terms of overcoming the public malaise and for reestablishing credibility and a leadership role in the world community. About a week before the end of the war, Bush (1991: 183) stated to reporters that upon the war's end, his hope would be that

we will have kicked, for once and for all, the so-called Vietnam syndrome ...And that sends a strong signal for the future - that we're credible, we're committed to peace, we're committed to justice, and we are determined to fulfill our obligations in trying to bring about a more peaceful world order. ${ }^{7}$

The Sociological Review, Vol 50, No. 4 (November 2002): pg. 587-609. DOI. This article is @ Blackwell Publishing and permission has been granted for this version to appear in e-Publications@Marquette. Blackwell Publishing does not grant permission for this article to be further copied/distributed or hosted elsewhere without the express permission from Blackwell Publishing. 
A few days after the war's end, Bush (1991: 233) announced that this goal had been achieved. Later in the day at a press conference, he remarked on several occasions about the new mood of patriotism overcoming the people. 'In towns and cities across this nation, our citizens have felt a sense of purpose and unity in the accomplishment of our military that is a welcome addition to the American spirit' (Bush, 1991: 234, 237, 238).

With these two goals - motivating support and re-igniting a vigorous American identity - in mind, Bush's discourse is replete with descriptions and anecdotes about what America and Americans are and what values and personality characteristics they supposedly hold in common. American national character according to Bush:

In the life of a nation, we're called upon to define who we are and what we believe. Sometimes these choices are not easy. (George Bush, 1990: 1216, as he announced to the nation the deployment of American troops to Saudi Arabia.)

We could safely assume, though, it has been documented as well, that a nation's self-assessment will often emphasize its real or perceived virtues over its weaknesses. Various studies have noted that numerous peoples have held or continue to hold a self-image of superiority, uniqueness, and/or chosenness. 8 Although America may be exceptional in a number of respects, it is no exception in that respect. Throughout its history, America's leaders and many of its elite, have gazed into the mirror, inquired 'who is the fairest country of them all?' and saw the answer reflecting back at them.

So, when in Executive Order 12722 (August 2, 1990), Bush declared Saddam Hussein's invasion a threat to American national security, he essentially began a seven-month esteem-building campaign. Bush's list of American qualities and his use of superlatives (the 'finest, most loving nation'10, 'greatest nation, freest nation'11, or 'only' nation $)^{12}$ indicated that he saw America as the unique embodiment of only the highest character qualities.

Once again, our people, the people of our country have come together to show the world our finest strengths: American optimism, unity, unselfishness, the world values of family, and 
the will to stand up for what's right and good - strengths that form the very heart of America and that make possible the freedoms our brave service men and women are striving to defend (Bush, 1990: 1410).

His list of American qualities was apparently unlimited, but I have grouped the various qualities into several larger categorise, 'esteemed values', 'active Americans,' 'unique leaders,' and 'brave and sacrificial,' all of which intersect within Bush's discourse.

\section{Esteemed values and qualities}

Several personal and political or civic values appeared repeatedly in Bush's rhetoric. First, Bush described Americans as a peace-loving people. However, Bush made it clear that peace-loving should not be confused with passivity or indecisiveness. Indeed, most common among the keywords defining America were 'standing,' 'determination,' 'resolute,' and 'steadfast.' For instance, in his speech to the Iraqis, Bush (1990: 1390) assured them that

No one - not the American people, not this President - wants war. But there are times when a country, when all countries who value the principles of sovereignty and independence, must stand against aggression. As Americans, we're slow to raise our hand in anger and eager to explore every peaceful means of settling our disputes; but when we have exhausted every alternative, when conflict is thrust upon us, there is no nation on Earth with greater resolve or stronger steadiness of purpose. ${ }^{14}$

Secondly, Bush elevated the value of friendship, particularly in the first two to three months of the crisis, when Bush used the designation of 'friend' to demarcate the world into two camps (i.e., basically those who voted with the United States at the United Nations or in the Arab League and those who did not), US 'friends' included the Western allies, particularly Britain, as a given. Bush made a point to say that Turkey, which allowed the United States use of military bases, was a "staunch friend." Saudi Arabia, Egypt, Jordan and Yemen were included on the list, but by mid-August, the latter two were in the process of losing that status due to their hesitancy to support US military action. Interestingly, Kuwait was not mentioned among the list 
of friends. Indeed, little was said about Kuwait until mid- to lateSeptember, shortly before the visit of Kuwait's Amir on the 28th. It was the Amir's first visit ever to the United States, which may help explain why Kuwait was not specifically mentioned on the US list of friends. Loyalty or commitment to friends became an important and repeated motive in the crisis. Bush assured the world that it would be a great mistake to underestimate America's commitment to imperiled friends. For example, Bush (1990: 1256) told Department of Defence employees: 'What is at stake is truly vital. Our action in the Gulf is about fighting aggression and preserving the sovereignty of nations. It is about keeping our word, our solemn word of honor, and standing by old friends." 15

Third, America was, by and large, a principled country, a country that was by nature part of something larger than itself, ${ }^{16}$ a country that would find it contrary to its nature to look aside when evil needs defeating or transcending principles require defending.

Standing up for our principles will not become easy...Standing up for our principle is an American tradition. As it has so many times before, it may take time and tremendous effort, but most of all, it will take unity of purpose. As I've witnessed throughout my life in both war and peace. America has never wavered when her purpose is driven by principle. And in this August day, at home and broad, I know she will do no less. ${ }^{17}$

Although standing up for principle was not easy, Bush (1990: 1410) claimed America had the necessary qualities, moral values, and will to do so, America's greatness as a country obligates it to act. In fact, these characteristics compel the country to a degree that virtually eliminates the option to choose not to become militarily involved. Hence, ironically the moral value of the action is reduced.

Six weeks ago we sent our troops half a world away because we were compelled by the moral compass that guides our nation. As Americans, we could not ignore this brutally aggressive act...

The highly esteemed political or civic principles worth fighting for varied throughout the seven months. Originally, Bush (1990: 1216-7) said the United States was defending four principles: withdrawal of Iraq from Kuwait, restoration of Kuwait's government, stability and 
security of the Persian Gulf region, and protection of America lives abroad. These later became the 'goals' of the military campaign, and the term principle was either left undefined or included any number of values. Most often principle included the New World Order, international order and the rule of law, fighting aggression, freedom, sovereignty or integrity, and political stability. Often principles were stated in colloquial language about keeping our word to friends and standing up to bullies or outlaws. ${ }^{18}$ Such language resonates with most Americans

\section{Active Americans}

Activity - whether working, striving, migrating, or being assertive and ambitious - has always had rhetorical appeal in America. Its value is exhibited in such phrases as 'actions speak louder than worsd' or 'forget the talk; let's see some action'. Thomas Hietala (1985: 95), in his study of late Jacksonian America, points out that Americans were viewed as 'go-ahead' people - adventurous, ingenious, inventive, innovative, practical and utilitarian, rather than contemplative and aesthetic (also Bormann, 1985: 489). To do nothing was seen as missing the opportunity to reform.

In that vein, Bush denigrated talking, debating, and negotiating. $\mathrm{He}$ (1990: 1243) reminded reporters that, unlike verbose Hussein, 'I am not one who flamboyantly believes in throwing a lot of words around. I'm more interested in action.' When demonstrators interrupted a Republican campaign speech in Chicago, Bush (1990: 1603) told his audience, 'I'm so glad we have free speech here, but once in a while, you know, we ought to get on with our business.' Bush's disdain for words or talk was also indicated in his unwillingness to allow negotiations, which were equated with 'compromise', 'flexibility', and 'appeasement' and were seen as weakness.

To illustrate that Americans are 'can-do people', 'movers and shakers', and go beyond what's required, Bush employed a number of heroic anecdotes about individual Americans. ${ }^{19}$ Most of these anecdotes were employed during a stint of speeches in support of various Republican candidates or during his Thanksgiving trip to visit armed forces stationed in Saudi Arabia. For instance, Bush related 
stories about a man who quickly arranged his wedding when he heard he was being deployed. 'You talk about a guy who gets things done!' Bush (1990: 1270) commented. He relayed other stories about a man who walked across the country to be able to serve the nation in the Persian Gulf (1990: 1410); about a 63-year-old grandmother, whose grandchildren called her 'Grambo' because she tried to enlist to serve in the Gulf (1990: 1461); and about a soldier who wanted to send Hussein an 'M.C.Hammer' tape to show Hussein that if this is how Americans entertain themselves, 'imagine how we fight' (1990:1906).

\section{World leader}

Given these unique character qualities and values, it was only logical that the United States be portrayed as the natural leader of the world and, as Loren Baritz (1985) says, the one all countries admire and hope to imitate. Consequently, Bush makes numerous statements that imply or state directly that other countries look to the United States for leadership and vision.

He called America the 'manifestation of humanity's timeless yearning to be free' (1990: 1903) and 'a beacon of hope and freedom to the entire world' (1990: 1410). He then quoted (1990: 1272) Teddy Roosevelt: America means many things, among them, equality of rights, and therefore, equality of duty and obligation. You know how America remains the hope of liberty-loving people everywhere.'

Likewise, although the Persian Gulf military effort was supposedly precipitated by United Nations resolutions, Bush's (1990: 1461) discourse indicated the United Nations was following the United States' lead, not vice versa:

Our effort is not Republican or Democrat or liberal or conservative: it is truly American - all American...Not only do we have 22 nations now, including many Arab states and the Soviet Union, on our side - well over half the Arab League, a vast majority - we have freedom and justice on our side. Our goals have been endorsed by the United Nations Security Council eight times...[T] here is no substitute for American leadership in the shaping of a new partnership of nations. 
This last statement eventually became a well-worn slogan of the seven-month campaign. For Bush, no other nation could meet the challenge, Bush (1990: 1601, 1603) proclaimed 'We have the responsibility to lead the United States does. If we don't stand up again aggression around the world when it's naked and brutal... who will?'; 'It is only the United States that can stand for principle.'

\section{Brave and suicidal}

If it is only the United States that can do the job, then it is fortunate that Americans are brave and sacrificial. Both of these qualities were most frequently applied to the soldiers who illustrated that 'America would not be the land of the free if it were not home of the brave'20 and whose 'uncommon sacrifice' was 'teaching all [Americans] a lesson about what it means to love liberty and the precious freedom that gives America its meaning. ${ }^{21}$

Bush defined sacrifice variously. In his Veteran's Day Proclamation, Bush (1990: 1612) described sacrifice as laying down life for a friend, or placing one's self in harm's way to defend others. But to a group of Nebraskans, Bush (1990: 1596) said that the soldiers' sacrifice was leaving spouses, children, and even Big Red football to defend our cause.' The varying language paints a national identity with which most people can identify, but it also motivates people to make what sacrifices they can to be part of that identity.

As he did with the 'active American' characterization, Bush used emotion-laden anecdotes, particularly in his campaign speeches, to make each American feel he/she could contribute to upholding these virtues. Each American could then be a hero in the myth. The stories included one about an 8-year-old girl who didn't want to see her daddy leave for the Gulf but knew it was necessary to make the world safe (1990: 1270) and another about a flight nurse who willingly left her baby to join her husband in the Gulf because, ultimately, they were fighting for the baby's future (1990: 1270). These human-interest stories about ordinary Americans help to define the strength of the American character under duress, or as Bush (1990: 1270) said, the protagonists of these stories 'show the true caliber of America'. 


\section{American national character according to the peace movement}

Unlike Bush's discourse, which as a presidential discourse set the tone and established the rhetorical framework of the crisis, peace movement discourse was more of a reaction to Bush's policy and discourse. While one of Bush's discursive intent was to draw the people into a motivating national identity, each peace group was attempting to recruit supporters into its particular collective identity. Hence, in the discourse of both groups, little overt attention is paid to defining the American national identity: rather, rhetoric about what defines America( $n$ ) is embedded in the discourse as secondary talk. To the extent that national identity constructs are present in their discourse, the two groups distinguish, though inconsistently, among the American government, America as a country, and the American people in their characterizations.

\section{America the government}

Unlike Bush, who gave little direct attention to characterizing the American government, the peace movement aimed much of its discourse at the current Administration or at the government generally. The peace movement acknowledged that the American government was formally a democracy and formally had a constitution. However, it also suggested that the current administration was failing to follow those principles and, in fact, was interpreting the Constitution to fit its own needs. Consequently, peace movement discourse portrayed the American government, not as an example to be emulated, but as deceptive and manipulative. The government was hypocritical in its stance opposed to the Iraqi occupation of Kuwait, while allowing the Israeli occupation. ${ }^{22}$ The Department of Energy had covered up the dangers of nuclear weapons production and 'duped' its own people. ${ }^{23}$ The Federal Bureau of Investigation was spying on Americans. ${ }^{24}$ The government was using the military to conceal the fraud that American diplomacy has become, and a significant number of Americans know that the government lies to them. ${ }^{25}$ As the war started, the peace movement charged that the American government was concealing the actual extent of destruction and death. ${ }^{26}$ 
In addition, peace groups characterized the American government as the cause of the crisis. According to peace movement discourse, prior US arms sales and a weak energy policy, in particular, facilitated Iraq's ability to attack its neighbor and America's dependence on Middle East oil. By placing US government actions in the active movement, peace movement discourse, attempted to show that the American government was an active obstacle to peace, rather than the peacemaker that Bush's discourse proposed. For instance, the peace movement charged that Bush 'ignored U.N. resolutions' and 'orchestrated a series of near unanimous Security Council votes with outright bribes'. ${ }^{27}$

\section{America the country}

On occasion, the MFSN framed America as an example to the world, but even that couched in the past tense.

We have sent out better images to the world: in our early years it was that of planters, growers, inventors, superior craftspeople and artists; then we added to our image as master builders, manufacturers, teachers, healers. These brought us great abundance and made us a beacon for countries like those in Eastern Europe who are adopting many of our cherished ways by example, where force would surely have failed to make them do so. ${ }^{28}$

America was a country originally founded on the principles of freedom of speech, press, and religion and liberty and justice for all. However, the MFSN was quick to add that the war was not about these principles. In fact, the MFSN pointed out that vigilantism or fighting without good reason 'is not an unusual idea in our history. There have always been many who would whip up a posse to go off and join a fight regardless of the state of our own affairs. Texans seem especially so disposed'. 29

Contrary to the exemplary past that may have existed, both groups painted current America as a country abusing the rest of the world and a country in dire straits. As to the former, the peace movement pointed out that the United States was the only country to have actually used the atomic bomb against another country. ${ }^{30}$ Hence,

The Sociological Review, Vol 50, No. 4 (November 2002): pg. 587-609. DOI. This article is @ Blackwell Publishing and permission has been granted for this version to appear in e-Publications@Marquette. Blackwell Publishing does not grant permission for this article to be further copied/distributed or hosted elsewhere without the express permission from Blackwell Publishing. 
it was the United States that should be most feared. In addition, peace movement discourse described the American 'way of life' as largely consisting of greed, consumption of an unfair share of the world's resources, and massive destruction of many life forms. ${ }^{31}$

In regard to the dire straits depiction, the key words were 'crumbling' and 'falling apart'. Both groups repeatedly indicated that the country was riddled with social problems - a deteriorating infrastructure and epidemics of homelessness, AIDS, and racism. It was a country that didn't care about its people.

Meanwhile our cities are falling apart, our unions are under attack everywhere, thousands of people are living in the streets, our hospitals and schools are collapsing. ${ }^{32}$

We are witnessing an alarming increase in racism here at home. ${ }^{33}$

There is something fundamentally wrong with a society that can offer 'equal job opportunity' only on the field of battle. ${ }^{34}$

[The nation] doesn't care about homeless people or education or health care for the poor as much as it cares about the fate of its missile systems... ${ }^{35}$

\section{America the people}

Both peace groups initially made one or two statements about the 'peace and justice sentiments of the American people'. Both groups used polling figures to indicate that the majority of American people were against this war. The MFSN characterized itself as patriotic (unlike the rest of the peace movement), and insofar as it also described itself as 'mainstream, main street American,' the group's discourse implied that most Americans were also patriotic.

However, the general tone of peace movement discourse portrayed Americans in a more negative light. The peace movement indicated that Americans were ignorant and easily duped by government. ${ }^{36}$ By the end of the war, NCPME, licking its wounds, said it frequently faced a hostile public opinion and described itself as the lone moral conscience in a sea of empty patriotic slogans. ${ }^{37}$ Moreover, 
the earlier characterization of American society as racist, uncaring, and greedy also impugned the American people, as society is, of course, comprised of its individual members.

\section{Discussion}

Though not normally approached as a means of socialization, public discourse at time of war offers an occasional, but intensive, 'teachable moment' for US leaders to socialize the nation's members about the place of their nation in the world community, what values are American, and what ways of acting are esteemed. Simultaneously, the officially proffered national identity becomes a contested terrain as the battle between the Administration and anti-war groups ensues.

In this particular case, President Bush utilized superlative qualities to entice the nation into a winsome collective identity that transcends the myriad of identities offered to the public in contemporary America and invites the people into a collaboration of virtue. Such identity construction helped to position the United States in relation to other countries in the international setting. In so doing, it assigned roles, behaviors, obligations and duties that members agree need to be carried out even if they as individuals would not support it. As a member of a nation that is defined as democratic, superior, and resourceful, the individual may feel resigned to war to fulfill those obligations to the nation or to the international community, a sacrifice of the part for the sake of the whole.

Stephen Browne (1991) argues that the essence of rhetoric is to invite the audience into an alliance in virtue, calling upon the audience to help the speaker participate in some form of redemption. This Browne refers to as 'speaker-hearer collaboration.' In this case, Bush's discourse on America's superb qualities and its role as the only qualified leader compelled by morals, obligated by its greatness, and enabled by the sacrifices of young and old, military and civilian, implied that it was the responsibility of Americans to support Bush policies and the troops he deployed. For instance, speaking to an audience in Florida, Bush (1990: 1331) stressed.

The Sociological Review, Vol 50, No. 4 (November 2002): pg. 587-609. DOI. This article is @ Blackwell Publishing and permission has been granted for this version to appear in e-Publications@Marquette. Blackwell Publishing does not grant permission for this article to be further copied/distributed or hosted elsewhere without the express permission from Blackwell Publishing. 
[There is] strong international support for what your sons and daughters are doing halfway around the world...

...[T] here is no substitute for the support of the American people. Under our system, you're the ones with the power.

You've got it in your hands. And I need your support, and I hope I have it as we continue to stand up against aggression in the Middle East...I am confident that with your support and the continued, concerted action of the world community, justice will prevail over the forces of aggression. [emphases mine]

Bush's call to collaborate in this collective action creates a sense of team-work and motivation to participate. The actions required from the people to exhibit this collective action, such as writing letters or sending games to the troops, are undemanding. They don't even have to give up the Superbowl, and yet they make possible victory over injustice and American leadership of the world (Bush, 1990: 1465).

However, such participation and membership also effects a redistribution of accountability. Agency then is shifted from Bush and his policies to the American people, who become, at least in part, responsible for the outcome. A lack of collaboration on the part of Americans, a lack of political will and consensus, could lead to failure and to the loss of American superiority and leadership position (Bush, 1990: 1362).

While Bush recognized (though only rarely) differences of opinion on the war or in a democracy generally, he repeatedly advocated that in this time of foreign policy crisis, those differences he left at the water's edge. Instead, unity is the face that should be shown to the world. This may account for Gallup poll data (December 1990: 9) that indicated that the majority of respondents who opposed military action (which until the war started was a majority of respondents) would nevertheless refrain from expressing their opposition through demonstrations, writing letters, and so forth. Fiftyeight percent of them said they would not take such actions. In January, however, peace demonstrations occurred at the start of the war. They were considered to be unusually large for the beginning of a war. But a majority of respondents (63\%) to Gallup's January 1991 poll indicated that the peace demonstrations were a bad thing for Americans to do when US troops are fighting overseas (Gallup, January 1991: 35). In fact, the percent opposed to demonstrations permission has been granted for this version to appear in e-Publications@Marquette. Blackwell Publishing does not grant permission for this article to be further copied/distributed or hosted elsewhere without the express permission from Blackwell Publishing. 
was higher among women (67\%), even though they were more likely opposed to military action.

Moreover, as indicated earlier, one of Bush's goals was to overcome the 'Vietnam syndrome', to dispel the malaise in American confidence about the nation's role in the world. The Gallup poll (March 1991: 21) addressed those issues after the war ended. While polling data have weaknesses and it would be impossible to pinpoint the cause of the results, the data do indicate that the nation's perception of the American identity and role was not disparaged by the war and its attendant discourse in the eyes of most Americans. Ninety-one percent of respondents say they had either quiet a lot or a great deal of confidence in the United States.38 85 percent said the same thing about the military (this was 17-35 percentage points higher than it had been at any time since 1973). Confidence in organized religion, Congress, and television also rose. In addition, 66 percent of respondents indicated they were satisfied with the way things were going in the United States, and that was the highest it had been in the past year. In July 1991, Gallup asked the nation about the US role in the world. Specifically, the poll asked respondents whether US prestige and influence had increased around the world. Seventy-nine percent thought US prestige had increased. Also, the poll inquired whether respondents thought the US was respected in the world more, less, or about the same as ten years earlier. Fifty-five percent thought it was respected more, compared to a 1982 poll in which 65 percent of respondents said the United States was less respected in the world.

The peace movement, on the other hand, by concentrating its discursive energy on carving out its own movement identity to recruit supporters, created, intentionally or not, a weak, uninviting national identity - a crumbling country full of well-intended but ignorant people and run by an incompetent, perhaps evil, government. This is an old strategy on the part of the peace movement, which has been criticized numerous times for its negativity and inability to relate to the general public (Ivie, 1987; Harvey, 1991; Miles, 1991). This strategy may account for the movement's recent inability to build a sustainable following. 
Repeated reliance on such a strategy occurs because the peace movement, particularly in a time of international crisis, faces a dilemma. As a social movement, its own collective identity is often, if not always, in opposition to the dominant order. If the movement attributes a national identity to the United States that is virtuous, it appears to be feeding into the ethnocentricity, the superiority, and the 'us v. they' dichotomy that the dominant collective identity professors. However, if it creates, wittingly or not, a negative national identity, even while it may be offering a positive collective movement identity, it alienates the public, as the urgency of a crisis situation doesn't allow any but those already jaundiced by the American way of life to claim the movement identity over the national identity.

Consequently, the peace movement, particularly NCPME (because that was one of the main groups that orchestrated the January demonstrations), was described at best as 'mainstream' (Roberts, 1991) but more frequently as 'poor excuses for Americans' (Cloud, 1991) and 'anachronistic' (Weisberg, 1991). After the war, even the alternative press counseled the peace movement to stop shaming Americans into joining the peace movement and to believe that most Americans are decent (Miles, 1991).

The peace movement needs to consider alternative strategies. As Antonio Gramsci (1971) has suggested in his analysis of the relationship of dominant and oppositional ideologies, the peace movement may need to co-opt some of the elements of dominant discourse so that it resonates with the larger public and offers them a national identity that unites them as Americans, calls them to collaborate in virtue, yet redefines the virtue. According to Gramsci, it is only logical that subordinate groups would not want to discard the existing dominant elements altogether, since they were already part of the generally accepted common sense and therefore carry some credibility and popularity. Many of the characteristics posed by Bush principled and peace-loving, but resolute, determined, steadfast; brave and sacrificial - were generic in the sense that they could easily be coopted by pro- and anti-war discourse. In fact, while a number of Bush's esteemed political values would seem to support the established geopolitical status quo (and be contrary to peace movement goals of change), some of those values (new world order, 
collective security) were co-opted originally from peace movement discourse (Coles, 1998).

This raises another question for future research: To what extent do these characteristics, posed by Bush as comprising the American national character, actually resonate with the people? To establish that both the president and social movements play a role in creating and defining a national identity does not preclude the possibility that the nation's members are oblivious to it or reject it. While Anthony Smith (1991) asserts that owning the national identity is a means to immortality, a way to avoid oblivion, as the individual becomes involved in an identity larger than him- or herself, in an identity that will likely outlive its individual members, he may be overstating the extent to which or the context in which individuals actually consciously claim national identity for themselves. Specifically, where incongruence between what is offered and what is claimed exists, we can ask whether there are variations by class, race and ethnicity, or gender? Public opinion research on war already indicates that women and ethnic minorities tend to be less supportive of military interventions and less likely to see any war as a just war (Gallup, January and February, 1991). To what extent could that be due to a weaker inclination among these groups to identify with the proffered national identity?

Finally, the peace movement could choose to advocate a transnational identity that attempts to draw people into a universal human identity. This may seem more conducive to a peace movement that sees nationalism as a reactionary discourse. However, the predominance of nationalist discourse, exhibited in Bush's discursive inclination to define America as above other nations, may confirm Andersen's (1991) thesis that a universal identity that transcends various national identities will have an uphill battle. Although other nations may seem themselves as determined, peace-loving, and sacrificial, a transnational identity would have to temper the use of the superlative and recognize some of the characteristics it claims for itself as common among all humanity. Some trends, such as globalization and the redefining of various individual European identities into one European identity, may be supplying cultural forces toward a universal identity. However, other trends, such as the rise of ethnic, religious, 
and other civil conflicts in Africa, the Balkans, the Middle East, and Central Asia, still indicate that national, rather than transnational or universal, identities will remain privileged for some time to come. This is well illustrated by the younger George Bush's words as he spoke to Americans while preparing for war in Afghanistan (Bush, 2001):

I applaud the American people for your courage in a time of trial. We're living through a unique moment in American history. This is a time of rediscovery of heroism and sacrifice and duty and patriotism. These are core values of our country, and they're being renewed... Our forefathers would be proud, really proud of what they see in America today. They would be proud of the selfless duty of the fire fighters and police officers of New York...Our forefathers would salute the modern-day sacrifice of the brave passengers on Flight 93...Our forefathers would know and recognize the spirit of unity and patriotism everywhere in our country...The true character of this great land has been revealed in adversity. Americans are generous to our neighbors in need...tolerant toward our fellow citizens...alert to danger, but calm and determined in the work ahead. And Americans are reaching out across the world to say: We wage war on the guilty, not the innocent...Americans know we must act now...We must stop the evil ones, so our children and grandchildren can know peace and security and freedom in the greatest nation on the face of the earth.

As his father before him, Bush's description of America's winsome virtues and ability to sacrifice invites Americans into that identity. However, Bush links being and doing: being virtuous is insufficient. Hence, he also invites Americans to complicity in action, action against the nonvirtuous. Hence, Bush's rhetorical strategy illustrates the enduring nature of national identity discourse and assures us that such discourse will remain powerful and a fruitful resource for farming foreign policy for some time to come. 
NOT THE PUBLISHED VERSION; this is the author's final, peer-reviewed manuscript. The published version may be accessed by following the link in the citation at the bottom of the page.

\section{Notes}

1. The outcomes of war may include the creation of anthems, new national heroes and enemies, changes in territorial boundaries and/or ethnic demographics and a boon to or drain on the economy, all of which could eventually impact national identity.

2. Of course, the necessary of these dualistic categories can't be tested, since humans are created and live in some degree of interaction by their nature. We will never know if one infant left on an isolated island would develop a sense of identity.

3. See Grundy and Weinstein (1974: 74) and Farrar (1978: 261) for an elaboration on the usefulness of this distinction.

4. See Coles, 1995, chapters 6 and 7 for elaboration on Bush's portrayal of Hussein.

5. Kennedy's book is discussed in Zagneki (1992: 372).

6. Quoted in Bostdorff and Goldzwig (1994: 517-18). See also Franklin Henry Giddings, a rhetoric of Manifest Destiny during the Spanish-American War, quoted in Grundy and Weinstein (1974: 53).

7. See also 'Remarks at the Annual Conference of the National Religious Broadcasters.' January 28, 1991, WCPD 27(5): 89.

8. For example, see Horseman (1981: 35), where he discusses the concept among the German people; Bass (1995) for a focus on Britain; Baritz (1964), Galtung (1987), Bormann (1985), and Weinberg (1935), for a look at US concepts of chosen people. Bormann traces these concepts back to the Puritan jeremiads of the 1600s, which have their roots in the Hebrew concept of the Jews as a chosen eople. See Dimont (1971) for the study of the concept of chosen people in Judaism. Most recently, see Hackett and Zhao (1994) who argue that America's master narrative in the 1991 Persian Gulf War was that of a chosen nation. Also, Lewis (1987) finds that Reagan relied on the 'chosen nation' myth during his presidency, and Stephanson (1995), makes a similar finding.

9. See deTocqueville (1948), Lipset (1996), and Shafer (1991) for various perspectives on American exceptionalism.

10. 'Radio Address to the Nation on the National Day of Prayer.' February 2, 1991, WCPD 27(6): 117.

11. Remarks at a Republican Campaign Rally in Tyler, Texas. November 5, 1990, WCPD 26(45): 1760.

12. See, for instance, the 'Address to the People of Iraq on the Persian Gulf Crisis' September 16, 1990, WCPD 26(38): 1390, in which Bush claims no nation on earth has greater resolve; or the 'Remarks at a Campaign Rally for Gubernatorial Candidate, Jim Edgar, in Chicago, Illinois,' October 16, 1990, WCPD 26(42): 1603, when Bush states that the

The Sociological Review, Vol 50, No. 4 (November 2002): pg. 587-609. DOI. This article is @ Blackwell Publishing and permission has been granted for this version to appear in e-Publications@Marquette. Blackwell Publishing does not grant permission for this article to be further copied/distributed or hosted elsewhere without the express permission from Blackwell Publishing. 
NOT THE PUBLISHED VERSION; this is the author's final, peer-reviewed manuscript. The published version may be accessed by following the link in the citation at the bottom of the page.

United States is the only nation that can stand for principle; or similarly in his 'Remarks at a Campaign Rally for Gubernatorial Candidate, Pete Wilson, in Los Angeles, California,' October 26, 1990, WCPD 26(43): 1668.

13. For a small portion of such instances, see also 'Remarks to Department of Defence Employees,' August 15, 1990, WCPD 26(33): 1255-1257; 'Remarks to the Military Airlift Command in Dhahran, Saudi Arabia,' November 22, 1990, WCPD 26(48): 1899; and 'Remarks and a Question-and-Answer Session with Reporters Following Discussions with Allies on the Persian Gulf Crisis,' December 17, 1990, WCPD 26(51): 2046

14. Similarly, see 'Radio Address to United States Armed Forces Stationed in the Persian Gulf Region,' August 29, 1990, WCPD 26(35): 1301; 'The President's News Conference,' January 12, 1991, WCPD 27(3): 39; and 'Address Before a Joint Session of the Congress on the State of the Union,' January 29, 1991, WCPD 27(5): 95.

15. See also 'Address to the Nation Announcing the Deployment of United States Armed Forces to Saudi Arabia,' August 8, 1990, WCPD 26(32), p. 1218; 'Remarks at the Annual Conference of the Veterans of Foreign Wars in Baltimore, Maryland,' August 20, 1990, WCPD 26(34), p.1269; 'The President's News Conference on the Persian Gulf Crisis,' August 30, 1990, WCPD 26(35): 1304; and 'Address Before a Joint Session of the Congress on the Persian Gulf Crisis and the Federal Budget Deficit,' September 11, 1990, WCPD 26(37): 1358-1363, for just a few of the references to standing by friends.

16. 'Address Before a Joint Session of the Congress on the State of the Union,' January 29, 1991, WCPD 27(5): 90; and 'Remarks to Community Members at Fort, Steward, Georgia,' February 1, 1991, WCPD 27(6): 113.

17. 'Address to the Nation Announcing the Deployment of United States Armed Forces to Saudi Arabia,' August 8, 1990, WCPD 26(32): 1218. See also 'Radio Address to United States Armed Forces Stationed in the Persian Gulf Region,' August 29, 1990, WCPD 26(35): 1301; and 'Remarks at a Republican Reception in Cincinnati, Ohio,' November 2, 1990, WCPD 26(44): 1733.

18. For instance, see 'Remarks to Department of Defence Employers,' August 15, 1990, WCPD 26(33): 1255-56: 'Remarks at a Fundraising Luncheon for Gubernatorial Candidate Pete Wilson in San Francisco, California,' September 19, 1990, WCPD 26(38): 1409; 'Address to the Nation Announcing the Deployment of US Armed Forces to Saudi Arabia,' August 8, 1990, WCPD 26(32): 1227; 'Remarks at the Annual Conference of Veterans of Foreign Wars in Baltimore, Maryland,' August 20, 1990, WCPD 26(34): 1269; 'Remarks at a Campaign Rally

The Sociological Review, Vol 50, No. 4 (November 2002): pg. 587-609. DOI. This article is @ Blackwell Publishing and permission has been granted for this version to appear in e-Publications@Marquette. Blackwell Publishing does not grant permission for this article to be further copied/distributed or hosted elsewhere without the express permission from Blackwell Publishing. 
NOT THE PUBLISHED VERSION; this is the author's final, peer-reviewed manuscript. The published version may be accessed by following the link in the citation at the bottom of the page.

for Gubernatorial Candidate Jim Edgar in Chicago, Illinois,' October 16, 1990, WCPD 26(42): 1602; and 'Remarks at a Fundraising Luncheon for Governor Mike Hayden in Topeka, Kansas,' September 5, 1990, WCPD 26(36): 1329.

19. Occasionally, his concern to show that he and other Americans are always doing something resulted in absurd or humorous statements. For instance, toward the beginning of the crisis, Bush took a weekend vacation in Kennebunkport. Reporters were questioning his ability to stay 'on top' of the crisis from Kennebunkport. When one reporter asked him what he was going to do that night, he replied, 'Might go fishing...or might tee it up...I'm going to sit idly by,' ('Exchange with Reporters Aboard Air Force One on the Persian Gulf Crisis,' August 10, 1990, WCPD 26(36): 1319.)

20. 'Remarks at a Fundraising Luncheon for Governor Mike Hayden in Topeka, Kansas,' September 6, 1990, WCPD 26(36): 1329. This statement can be found frequently in Bush's discourse.

21. 'Remarks at a Republican Campaign Rally in Manchester, New Hampshire,' October 23, 1990 WCPD 26(43): 1643; and 'Remarks at a Funding Raiding Dinner for Gubernatorial Candidate John Rowland in Stanford, Connecticut,' October 23, 1990, WCPD 26(34): 1650.

22. NCPME, 'Iraq and Palestine: The Bush Administration's Double Standard on Occupation,' Part of a bulk mailing to member organizations, $1 / 7 / 91$.

23. Jacobs, Mary, 'My Turn: A Response to President Bush's Baloney Dinner on Thanksgiving,' A letter written by an MFSN member and mailed to members and the media, 11/28/90.

24. Letter written by the Center for Constitutional Rights and distributed in an NCPME bulk mailing, 1/15/91.

25. 'Statement to President Bush on the Persian Gulf Crisis by Relatives of Military Personnel,' MFSN, 10/10/90, p. 2.

26. Statement distributed in NCPM bulk mailing, 1/18/91.

27. 'Draft Political Statement' of the NCPME, 2/13/91 and 'Iraq and Palestine: The Bush Administration's Double Standard on Occupation,' a bulk mailing distributed by the NCPME, 1/2/01, p.1.

28. 'Remarks for Press Conference in Concord, New Hampshire,' MFSN state coordinator Richard Cornelius, 12/6/90, p. 2.

29. Remarks for Press Conference in Concord, New Hampshire,' MFSN state coordinator Richard Cornelius, 12/6/90, p. 1.

30. Jacobs, Mary, 'My Turn: A Response to President Bush's Baloney Dinner on Thanksgiving,' A letter written by an MFSN member and mailed to members and the media, $11 / 28 / 90$.

31. Jacobs, Mary, 'My Turn: A Response to President Bush's Baloney Dinner on Thanksgiving,' A letter written by an MFSN member and mailed to

The Sociological Review, Vol 50, No. 4 (November 2002): pg. 587-609. DOI. This article is @ Blackwell Publishing and permission has been granted for this version to appear in e-Publications@Marquette. Blackwell Publishing does not grant permission for this article to be further copied/distributed or hosted elsewhere without the express permission from Blackwell Publishing. 
members and the media, $11 / 28 / 90$, p. 5, and Alex Molnar, 'If My Marine Son Is Killed,' a letter published in The New York Times, $8 / 23 / 90$.

32. NCPMF, 'Bush's War Drive Sparks Massive Opposition,' Press release, January 1991. Also, Jim Grover, Connecticut state MFSN coordinator speech, January 1991, p. 7.

33. NCPME letter to membership, $12 / 31 / 90$, p. 1.

34. Draft of Op-ed piece included in NCPME bulk mailing, 2/1/91, p. 2.

35. Jacobs, Mary, 'My Turn: A Response to President Bush's Baloney Dinner on Thanksgiving,' A letter written by an MFSN member and mailed to members and the media, 11/28/90.

36. Letter from Center for Constitutional Rights, included in NCPME bulk mailign, 1/15/91, and Draft Statement of the NCPME, January 1991.

37. 'Antiwar Movement Continues,' NCPME press release, 2/26/91.

38. This was the first time Gallup had asked this question, so there was no comparison point.

\section{References}

Anderson, B. (1991). Imagined Communities: Reflections on the Origin and Spread of Nationalism, Second Edition. London: Verso.

Baritz, L. (1964). City on a Hill: A History of Ideas and Myths in America. New York: Wiley.

Barnet, R.J. (1990). The Rockets' Red Glare: When America Goes to War, The Presidents and the People. NY: Simon and Schuster.

Bass, J.D. (1995). The Perversion of Empire: Edmund Burke and the Nature of Imperial Responsibility, Quarterly Journal of Speech, 81(2): 208227.

Bennett, W.L. (1980). 'Myth, Ritual, and Political Control', Journal of Communication, 30(4): 166-179.

Billig, M. (1995). Banal Nationalism. London: Sage Publications.

Bloom, W. (1990). Personal Identity, National Identity, and International Relations. Cambridge: Cambridge University Press.

Bormann, E.G. (1985). The Force of Fantasy: Restorign the American Dream, Carbondale, IL: Southern Illinois University Perss.

Bostdorff, D.M., and Goldzwig, S.R. (1994). 'Idealism and Pragmatism in American Foreign Policy Rhetoric: The Case of Jonh F. Kennedy and Viet Nam', Presidential Studies Quarterly, XXIV (3): 515-530.

Browne, S.H. (1991). 'Edmund Burke's Discontents and the Interpretation of Political Culture', Quarterly Journal of Speech, 77(1): 53-66.

Burke, K. (1995). Permanence and Change: An Anatomy of Purpose, NY: The Bobbs-Merrill Co., Inc. 
NOT THE PUBLISHED VERSION; this is the author's final, peer-reviewed manuscript. The published version may be

accessed by following the link in the citation at the bottom of the page.

Bush, George. (1990). Weekly Compilation of Presidential Documents, 26: 32-52.

Bush, George. (1991). Weekly Compilation of Presidential Documents, 27: 113.

Bush, George W. (2001). President outlines war effort: Remarks by the President at the California Business Association Breakfast.

Sacramento, California, The White House, www.whitehouse/gov/news/release/2001.

Calhoun, C. (1997). Nationalism, Minneapolis University of Minnesota Press.

Clark, M. M. (1986). 'The Cultural Patterning of Risk-seeking Behavior: Implications for Armed Conflict,' in Foster, M.I., and Rubinstein, R.A. (eds), Peace and War: Cross Cultural Perspectives, New Brunswick, NJ: Transaction Books.

Cloud, S.W. (1991). Exorcising an old demon, Time, March 11 (1991): 52-53. Cloud, S.W. (1991). Shooting the messenger, Time, February 18 (1991): 34.

Coles, R.L. (1999). Odd folk and ordinary people: Collective identity disparities between peace groups in the Persian Gulf crisis. Sociological Spectrum, 19(3): 325-358.

Coles, R.L. (1998). Peaceniks and Warmongers' Framing Fracas on the Home Front Dominant and Opposition Discourse Interaction During the Persian Gulf War, The Sociological Quarterly, 39 (3): 369-391.

De Tocqueville, A. (1948). Democracy in America, NY: Alred A. Knopf. Dimont, M. (1971). The Indestructible Jews: Is There a Manifest Destiny in Jewish History? New York: New American Library.

Dionisopoulos, G.N., and Goldzwig, S.R. (1992). 'The Meaning of Vietnam: Political Rhetoric As Revisionist Cultural History,' Quarterly Journal of Speech, 78(1): 61-79.

Fanon, F. (1968). The Wretched of the Earth, NY: Grove Press.

Farrar, L.L. (ed.). (1978). WAR: A Historical, Political and Social Study, Studies in International and Comparative Politics, Santa Barbara, CA: ABC-Clio, Inc.

Friedman, D. and McAdam, D. (1992). 'Collective Identity and Activism: Networks, Choices, and the Life of a Social Movement', in Morris, A.D. and McClurg Mueller, C. (eds), Frontiers in Social Movement Theory, New Haven: Yale University Press.

Gallup, George Jr. and Frank Newport. (1990). Hostage Release Doesn't Change American Views of Persian Gulf Crisis, Gallup Poll Monthly (December) 1990: 7-17.

Gallup telephone survey results. (1991). Victory's aftermath: American confidence soars, Gallup Poll Monthly (March): 18-21.

Galtung, J. (1987). US Foreign Policy as Manifest Theology, LaJolla, CA: University of California Institute on Global Conflict and Cooperation.

The Sociological Review, Vol 50, No. 4 (November 2002): pg. 587-609. DOI. This article is @ Blackwell Publishing and permission has been granted for this version to appear in e-Publications@Marquette. Blackwell Publishing does not grant permission for this article to be further copied/distributed or hosted elsewhere without the express permission from Blackwell Publishing. 
NOT THE PUBLISHED VERSION; this is the author's final, peer-reviewed manuscript. The published version may be accessed by following the link in the citation at the bottom of the page.

Gramsci, A. (1971). Selections from the Prison Notebooks of Antonio Gramsci, edited by O. Hoare and G. Nowell Smith, NY: International Publishers.

Greenhouse, C.J. (1986). 'Fighting for Peace', in LeCron Foster, M. and Rubinstein, R. (eds). Peace and War: Cross Cultural Perspectives, New Brunswick, NJ: Transaction Books.

Grundy, K.W. and Weinstein, M.A. (1974). The Ideologies of Violence, Columbus, $\mathrm{OH}$ : Charles F. Merrill Publishing Company.

Hackett, R.A. and Zhao, Y. (1994). 'Challenging a master narrative: peace protest and opinion/editorial discourse in the US press during the Gulf War', Discourse and Society, 5(4): 509-541.

Harvey, M. (1991). 'Why Did the Anti-War Movement Flop?', Olne Reader, July/August, 17-18.

Hedetoft, U. (1993). 'National Identity and Mentalities of War in Three C Countries', Journal of Peace Research, 30(3): 281-300.

Hietala, T.R. (1985). Manifest Design: Anxious Aggrandizement in Late Jacksonian America, Ithaca: Cornell University Press.

Holsti, O.R. (1962). 'The Belief System and National Images: A Case Study', Journal of Conflict Resolution, 6: 244.

Horseman, R. (1981). Race and Manifest Destiny: The Origins of American Racial Anglo-Saxonism, Cambridge: Harvard University Press.

Hunt, S.A. and Benford, R.D. (1994). 'Identity Talk in the Peace and Justice Movement', Journal of Contemporary Ethnography, 22(4): 488-517.

Hunt, S.A., Benford, R.D., and Snow, D.A. (1994). 'Identity Fields: Framing Processes and the Social Construction of Movement Identities', in Larana, F., Johnson, H., and Gusfield, J.R. (eds), New Social Movements: From Ideology to Identity, Philadephia: Temple University Press.

Ivie, R.L. (1974). 'Presidential Motives for War', Quarterly Journal of Speech, 60(3): 337-345.

Ivie, R.L. (1987). 'Metaphor and the Rhetorical Invention of Cold War Idealists', Communication Monographs, 54 (June): 165-181.

Kennedy, P.M. (1987). The Rise and Fall of the Great Powers: Economic Change and Military Conflict from 1500 to 2000, NY: Random House.

Lewis, W.F. (1987). 'Telling America's Story: Narrative Form and the Reagan Presidency', Quarterly Journal of Speech, 73(3): 280-302.

Lipset, S.M. (1996). American Exceptionalism: A Double-Edged Sword, NY: WW Norton and Co.

McCrone, D., Stewart, R., Kiely, R., and Bechhofer, F. (1998). 'Who are we? Problematizing national identity', The Sociological Review, 46(4): 629652.

Miles, S. (1991). 'Ten Tips for the New Peace Movement', Mother Jones, 16(2): 14

The Sociological Review, Vol 50, No. 4 (November 2002): pg. 587-609. DOI. This article is @ Blackwell Publishing and permission has been granted for this version to appear in e-Publications@Marquette. Blackwell Publishing does not grant permission for this article to be further copied/distributed or hosted elsewhere without the express permission from Blackwell Publishing. 
NOT THE PUBLISHED VERSION; this is the author's final, peer-reviewed manuscript. The published version may be

accessed by following the link in the citation at the bottom of the page.

Miroff, B. (1998). 'From 'Midcentury to Fin-de-Siecle: The Exhaustion of the Presidential Imagine', Rhetoric and Public Affairs, 1(2): 185-199.

Murphy, J.M. (1992). 'Epideictic and Deliberative Strategies in Opposition to War: The Paradox of Honor and Expediency', Communication Studies, 43(2): 65-78.

Nagel, J. (1994). 'Constructing Ethnicity: Creating and Recreating Ethnic Identity and Culture', Social Problems, 41: 153-176.

Norton, A. (1988). Reflection on Political Identity, Baltimore: John Hopkins University Press.

Neumann, J. B. (1999). Uses of the Other: 'The East' in European Identity Formation, Minneapolis: University of Minnesota Press.

Noonan, R. (1995). 'Women Against the State: Political Opportunities and Collective Action Frames in Chile's Transition to Democracy', Sociological Forum, 10: 81-111.

Roberts, Steven V. (1991). Not all quiet on the Western front, US News and World Report, January 28 (1991): 43.

Rojo, L.M. (1995). 'Division and Rejection: From the Personification of the Gulf Conflict to the Demonization of Saddam Hussein', Discourse and Society, 6(1): 49-80.

Rose, R. (1991). The Postmodern President George Bush Meets the World. Second Edition. Chatham, NJ: Chatham House.

Schlesinger, P., (1999). 'Collective Identities, Friends, Enemies', Innovation: The European Journal of Social Sciences, 12(4): 461-469.

Schlesigner, P. (1991). 'Collective Identities in a Changing Europe', Innovation: The European Journal of Social Sciences, 4(1): 41-64.

Schlesinger, P. (1987). 'On national identity: Some conceptions and misconceptions criticized', Social Science Information, 26(2): 219-264.

Shafer, B.F., ed. (1991). Is America Different? A New Look at American Exceptionalism, Oxford: Clarendon Press.

Shils, E. (1995). 'Nation, nationality, nationalism and civil society', Nations and Nationalism: 93-118.

Shlapentoka, D. (1994). 'The Chechen War and Russia's Identity Crisis', Contemporary Review, 270(1573): 72-77.

Slotkin, R. (1992). Gunfighter Nation: The Myth of the Frontier in TwentiethCentury America, NY: Atheneum.

Smith, A.D. (1991). National Identity, Reno: University of Nevada Press.

Sorel, G. (1941). Reflections on Violence, NY: Peter Smith.

Spellman, B.A. and Holyoak, K. J. (1992). 'If Saddam's Hitler Then Who Is George Bush? Analogical Mappign Between Systems of Social Roles', Journal of Personality and Social Psychology, 62(6): 913-933.

Stephanson, A. (1995). Manifest Destiny: American Expansionism and the Empire of Right, New York: Hill and Wang.

The Sociological Review, Vol 50, No. 4 (November 2002): pg. 587-609. DOI. This article is @ Blackwell Publishing and permission has been granted for this version to appear in e-Publications@Marquette. Blackwell Publishing does not grant permission for this article to be further copied/distributed or hosted elsewhere without the express permission from Blackwell Publishing. 
NOT THE PUBLISHED VERSION; this is the author's final, peer-reviewed manuscript. The published version may be

accessed by following the link in the citation at the bottom of the page.

Stoecker, R. (1995). 'Community, Movement, Organization: The Problem of Identity Convergence in Collective Action', The Sociological Quarterly, 36(1): 111-130.

Stuckey, M.E. (1992). 'Remembering the Future: Rhetorical Echoes of World War II and Vietnam in George Bush's Public Speech on the Gulf War', Communication Studies, 43(4): 246-256.

Stuckey, M.E. (1995). 'Competing Foreign Policy Visions: Rhetorical Hybrids After the Cold War', Western Journal of Communication, 59(3): 214227.

Swart, W.J. (1999). 'Constructing the 'Self' of Self-Determination: Liberal and Anti-Liberal Tensions in Modern Irish Nationalism', Social Thought and Research, 22(1 and 2): 139-166.

Tarrow, S. (1992). 'Mentalities, Political Cultures, and Collective Action Frames: Constructing Meaning Through Action', in Morris, A.D. and Mueller, C.M. (eds), Frontiers in Social Movement Theory, New Haven: Yale University Press.

Taylor, V. and Whittier, N. (1992). 'Collective Identity in Social Movement Communities' in Morris, A.D. and Mueller, C.M. (eds), Frontiers in Social Movement Theory, New Haven: Yale University Press.

Thompson, A. (2001). 'Nations, national identity and human agency: putting people back into nations', The Sociological Review, 49(1): 18-32.

Togeby, L. (1994). 'The Gender Gap in Foreign Policy Attitudes', Journal of Peace Research, 31(4): 375-392.

Triandafyllidou, A. (1999). 'Nation and Immigration: A Study of the Italian Press Discourse', Social Identities, 5(1): 65-88.

Wander, P. (1984). 'The Rhetoric of American Foreign Policy', The Quarterly Journal of Speech, 70(4): 339-361.

The Weekly Compilation of Presidential Documents. (1990 and 1991). Vols. 26(31-52) and 27(1-9). Washington, D.C.: US Government Printing Office.

Weinberg, A.K. (1935). Manifest Destiny: A Study of Nationalist Expansion in American History, Chicago: Quadrangle Books.

Wendt, A. (1994). 'Collective Identity Formation and the International State', American Political Science Review, 88(2): 384-396.

Wilmer, F. (1997). 'Identity, Culture, and Historicity: The Social Construction of Ethnicity in the Balkans', World Affairs, 160(1): 3-16.

Zagacki, K.S. (1992). 'The Rhetoric of American Decline: Paul Kennedy, Conservatives, and the Solvency Debate', Western Journal of Communication, 56(4): 372-393.

The Sociological Review, Vol 50, No. 4 (November 2002): pg. 587-609. DOI. This article is @ Blackwell Publishing and permission has been granted for this version to appear in e-Publications@Marquette. Blackwell Publishing does not grant permission for this article to be further copied/distributed or hosted elsewhere without the express permission from Blackwell Publishing. 